\title{
Pelatihan Keterampilan Konseling Sebaya dalam Bidang Kesehatan Reproduksi Remaja
}

\author{
Peer Counseling Skills Training in Youth Reproductive Health
}

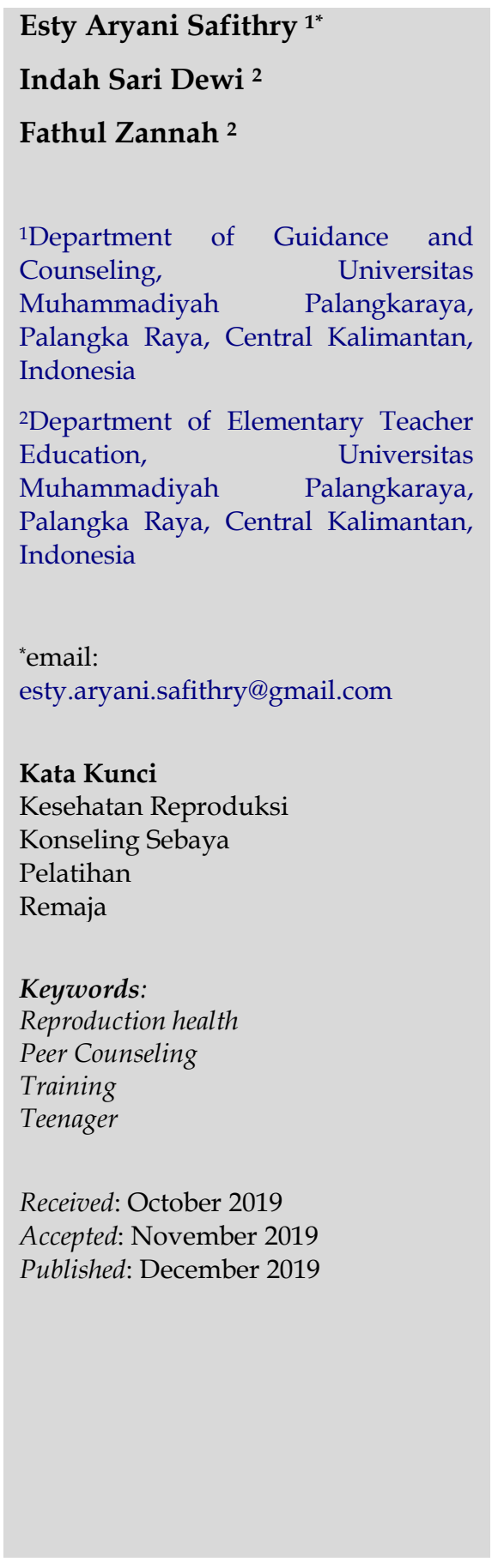

\begin{abstract}
Abstrak
Keingintahuan yang besar pada remaja untuk menjelajahi segala hal seringkali tidak dibarengi dengan pertimbangan yang matang, hingga terkadang tindakan-tindakannya berisiko baik bagi diri sendiri, orang lain, dan lingkungan di sekitarnya. Salah satu masalah yang bisa timbul adalah masalah kesehatan reproduksi. Pelatihan ini mengambil lokasi di SMK Kesehatan Muhammadiyah Palangkaraya dan SMAN 1 Palangka Raya dengan alasan yaitu berdasarkan hasil wawancara dan angket mengenai pengetahuan tentang kesehatan reproduksi remaja yang masih dalam kategori rendah, belum adanya dilaksanakan pelatihan serupa di sekolah tersebut, dan siswa di SMK tersebut masih remaja juga karena mereka bergerak di bidang kesehatan yang akan terjun ke lingkungan masyarakat dan kemudian dapat mengedukasi mengenai Kesehatan Reproduksi Remaja. Kelompok teman sebaya dapat dijadikan sebagai pengganti keluarga, dapat berfungsi menstabilkan pengaruh selama masa transisi sebagai sumber memperoleh harga diri, perlindungan dari paksaan orang dewasa. Konseli-konseli yang memanfaatkan layanan konseling sebaya mampu melakukan identifikasi diri dengan teman sebaya mereka dan para konseli menganggap bahwa konselor sebaya memiliki kemauan membangun jembatan komunikasi. Hasil dari kegiatan ini menunjukan bahwa ada peningkatan nilai rerata keterampilan konseling sebaya pada bidang kesehatan reproduksi remaja. Nilai rerata pre-test adalah 40,8 dan rerata post-test adalah 67,4 .
\end{abstract}

\begin{abstract}
The great curiosity of adolescents to explore things is often not accompanied by careful consideration so that sometimes the actions are risky for themselves, others, and the surrounding environment. One problem that can arise is reproductive health problems. This training took place at the Muhammadiyah Health Vocational School in Palangkaraya and State High School 1 Palangka Raya with the reason that based on the results of interviews and questionnaires about knowledge of adolescent reproductive health which was still in the low category, no similar training had been carried out at the school. Students at the Vocational School are still teenagers too because they are engaged in health, which will go into the community and can then educate on Adolescent Reproductive Health. Peer groups can be used as a substitute for family, can function to stabilize the influence during the transition as a source of self-esteem, protection from adult coercion. Counselors who use peer counseling services can identify themselves with their peers, and the counselees assume that peer counselors have a willingness to build communication bridges. The results of this activity indicate that there is an increase in the average value of peer counseling skills in the field of adolescent reproductive health. The mean pre-test was 40.8 , and the posttest mean was 67.4.
\end{abstract}




\section{PENDAHULUAN}

Remaja memiliki rasa keingintahuan yang besar dan cenderung ingin mengeksplorasi dunia. Seringkali hasrat untuk menjelajahi segala hal ini tidak dibarengi dengan pertimbangan yang matang, hingga terkadang tindakan-tindakannya berisiko tinggi baik bagi diri sendiri, orang lain, dan lingkungan di sekitarnya. Apabila tidak diberi perhatian dan dibiarkan tanpa pengawasan, perbuatan berisiko ini dapat memunculkan berbagai masalah. Salah satu masalah yang bisa timbul akibat perilaku tersebut adalah masalah kesehatan reproduksi (Elvianasti \& Roza, 2019).

Menurut WHO dan ICPD (International conference on Population and Development) pada Tahun 1994 yang diselenggarakan di Kairo kesehatan reproduksi adalah keadaan sehat yang menyeluruh, meliputi aspek fisik, mental dan sosial dan bukan sekedar tidak adanya penyakit atau gangguan segala hal yang berkaitan dengan sistem reproduksi, fungsinya maupun proses reproduksi itu sendiri (Filho et al., 2011).

Jumlah remaja umur 10-19 tahun di Indonesia terdapat sekitar 43 juta atau 19,61\% dari jumlah Penduduk Indonesia sebanyak 220 juta. Sekitar 1 juta remaja pria (5\%) dan 200 ribu remaja wanita (1\%) menyatakan secara terbuka bahwa mereka pernah melakukan hubungan seksual. Sebanyak 8\% pria umur 15-24 tahun telah menggunakan obat-obatan terlarang. Sedangkan untuk kasus HIV/AIDS dari 6987 penderita AIDS, 3,02\% adalah kelompok usia 15-19 tahun dan 54,77\% adalah kelompok usia 20-29 tahun (Astuty, 2013; Alyas, 2011).

Masalah yang menonjol di kalangan remaja yaitu permasalahan seputar Triad Kesehatan Reproduksi Remaja (KRR) yaitu Seksualitas, HIV/AIDS dan NAPZA. Hasil Survei Demografi Kesehatan Indonesia (SDKI) tahun 2012 Kesehatan Reproduksi Remaja menunjukkan bahwa 9,3 remaja menyatakan pernah melakukan hubungan seksual pranikah. Pada kasus
HIV baru tahun 2011, diperoleh bahwa 18\% diantaranya merupakan anak kelompok usia 15-24 tahun (Fitriyani, 2016).

Rendahnya pemahaman remaja tentang kesehatan reproduksi belum memadai dapat dilihat dengan hanya $35,3 \%$ remaja perempuan dan $31,2 \%$ remaja laki-laki usia 15-19 tahun mengetahui bahwa perempuan dapat hamil dengan satu kali berhubungan seksual. Pemahaman remaja tentang Infeksi Menular Seksual (IMS) masih rendah dimana hanya 35\% wanita dan 19\% pria mengetahui gonorrhea, $14 \%$ wanita dan $4 \%$ pria mengetahui genital herpes sedangkan jenis IMS lain dibawah $1 \%$. Informasi tentang HIV lebih banyak diterima oleh remaja, meskipun hanya 9,9\% remaja perempuan dan 10,6\% laki-laki memiliki pengetahuan yang komprehensif mengenai HIV/AIDS. Sebanyak 55,6\% siswa SMP kurang mengerti akan dampak narkoba yang dapat menyebabkan penurunan kesadaran hingga kematian. Pengenalan kesehatan reproduksi pada remaja menjadi bekal penting generasi penerus tersebut untuk mengarungi masa depannya (Purbono et al., 2015).

Alasan mengapa pengetahuan tentang remaja tentang kesehatan reproduksi masih rendah karena Pertama, remaja tidak tahu harus bertanya pada siapa dan di mana tentang kesehatan produksi. Kedua, akses pada informasi yang baik dan benar tentang kesehatan reproduksi sangat terbatas (peran guru, orangtua, teman sebaya, PIK, dan media massa). Ketiga, komunikasi efektif orangtua-remaja tentang kesehatan produksi masih dianggap tabu. Keempat, informasi kesehatan produksi tak dipelajari di sekolah sebagai bagian dari kuriklum. Kelima, pengetahuan orangtua yang terbatas soal kesehatan produksi. Keenam, pengaruh norma sosial budaya dan agama di masyarakat yang kurang mendukung remaja mengakses informasi kesehatan produksi. Terakhir, berbagai informasi di media yang 
menyesatkan, menyebabkan kehidupan seksualitas remaja tak sehat dan tak bertanggung jawab (Muslikah et al., 2016).

Dalam perkembangannya, individu tidak dapat terlepas dari hubungannya dengan kelompok sosial lainnya, misalnya kelompok teman sebaya. Lingkungan/ kelompok ini akan ikut menentukan bagaimana individu itu berkembang. Tidak menutup kemungkinan adanya sifat kesebayaan ini, justru individu akan memperoleh keuntungan tertentu, antara lain bahwasanya kelompok teman sebaya dapat dijadikan sebagai pengganti keluarga, dapat berfungsi menstabilkan pengaruh selama masa transisi sebagai sumber memperoleh harga diri, perlindungan dari paksaan orang dewasa (Rizqi et al., 2017). Konseli-konseli yang memanfaatkan layanan konseling sebaya mampu melakukan identifikasi diri dengan teman sebaya mereka dan para konseli menganggap bahwa peer counselor (Konselor Sebaya) memiliki kemauan membangun jembatan komunikasi (Muslikah et al., 2016).

Pelatihan ini mengambil lokasi di SMK Kesehatan Muhammadiyah Palangkaraya dengan alasan diantaranya (1) berdasarkan hasil wawancara dan angket mengenai pengetahuan tentang kesehatan reproduksi remaja yang masih dalam kategori kurang (2) belum adanya dilaksanakan pelatihan serupa di sekolah tersebut, serta (3) siswa di SMK tersebut masih remaja juga karena mereka bergerak di bidang kesehatan yang akan terjun ke lingkungan masyarakat dan kemudian dapat mengedukasi mengenai Kesehatan Reproduksi Remaja.

\section{METODOLOGI}

Alat atau bahan yang digunakan dalam pelaksanaan pengabdian adalah sebagai berikut:
1. Modul Pelatihan Keterampilan Konselor

Materi modul pelatihan keterampilan konselor sebaya dalam bidang kesehatan reproduksi remaja berisi bahan yang berkaitan dengan keterampilan konselor sebaya dalam bidang kesehatan reproduksi remaja berdasarkan analisis kebutuhan yang dapat meningkatkan keterampilan konselor sebaya dalam bidang kesehatan reproduksi remaja sebagaimana disajikan pada Gambar 1.

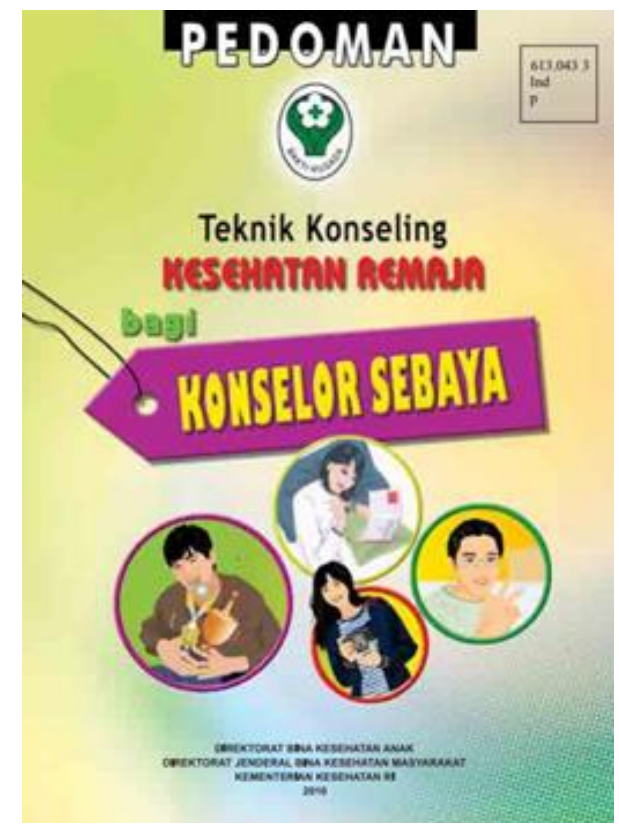

Gambar 1. Modul Teknik Konseling kesehatan remaja bagi konselor sebaya

2. Lembar kerja subjek bimbingan (LKS)

LKS dibuat berdasarkan pada materi pelatihan keterampilan konselor sebaya dalam bidang kesehatan reproduksi remaja.

3. Lembar observer terhadap konselor sebaya.

Lembar observer diberikan kepada pengamat untuk mengamati kemampuan konseling perserta.

4. Modul pelatihan pelayanan kesehatan peduli remaja (PKPR) bagi konselor sebaya

Modul ini diterbitkan oleh direktorat Bina Kesehatan Anak Kemenkes RI sebagaimana disaijkan pada Gambar 2. 


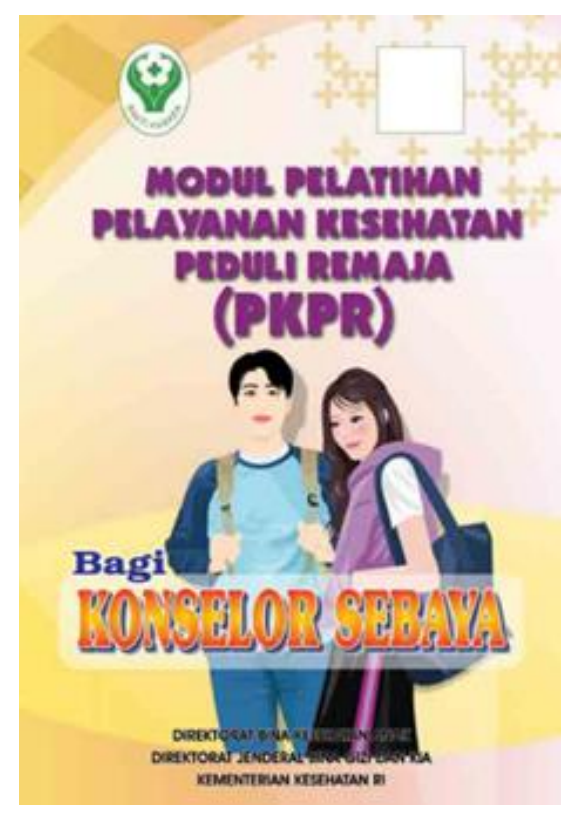

Gambar 2. Modul Pelatihan PKPR

Metode pelaksanaan dibagi menjadi sembilan sesi, dengan penjelasan sebagai berikut:

1. Sesi Pertama: Pretest dan Pemberian informasi

Kegiatan pretest dilaksanakan pada 8 Agustus 2019. Pertemuan awal dimulai dengan membangun rapport dan membagikan pretest sebagaimana ditunjukan pada Gambar 3. Tujuan pelaksanaan kegiatan ini adalah untuk mengetahui tingkat pemahaman siswa mengenai kesehatan reproduksi remaja dan pemberian informasi mengenai Seksualitas, HIV/AIDS, dan NAPZA. Tujuan kegiatan ini adalah untuk memberikan informasi kepada siswa mengenai mengenai tiga permasalahan kesehatan reproduksi remaja yaitu Seksualitas, HIV/AIDS, dan NAPZA.

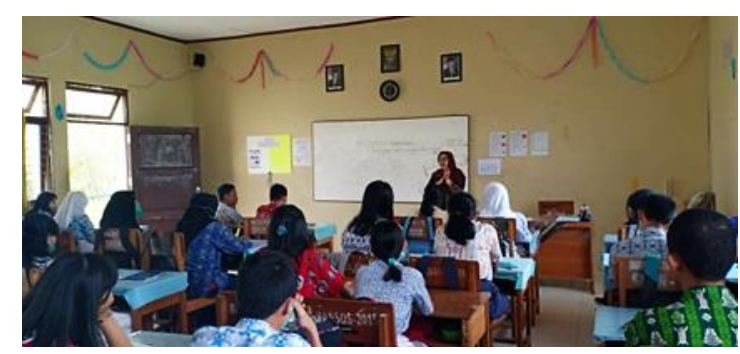

Gambar 3. Pretest dan pengantar kegiatan di SMAN 1 Palangka Raya
2. Sesi kedua: Keterampilan Attending

Dilaksanakan pada tanggal 9 Agustus 2019. Pada sesi ini, siswa sudah mulai mempraktikkan tingkah laku attending seperti keterlibatan postur tubuh, gerak tubuh secara tepat, kontak mata, serta membuat lingkungan menjadi nyaman. Tujuan dari keterampilan attending yaitu diharapkan siswa mampu membedakan tingkah laku attending nonverbal yang tidak efektif serta mampu mengkomunikasikan tingkah laku attending nonverbal yang efektif.

3. Sesi ketiga: Keterampilan Berempati

Pelatihan keterampilan ini bertujuan untuk melatih siswa berempati yang merupakan salah satu kunci untuk dapat meningkatkan kualitas komunikasi antar individu. Tujuan keterampilan berempati ini diharapkan siswa mampu mengidentifikasi perasaan-perasaan orang lain dan siswa mampu merespon secara empatik perasaan-perasaan yang diungkapkan oleh orang lain.

4. Sesi keempat: Keterampilan Bertanya

Dilaksanakan pada tanggal 12 Agustus 2019. Kegiatan pada sesi keempat merupakan pelatihan keterampilan bertanya yang merupakan salah satu bagian terpenting dari suatu dialog antara konselor dengan konseli. Tujuan keterampilan ini yaitu diharapkan siswa mampu memahami pertanyaanpertanyaan yang baik, siswa mampu menggunakan pertanyaan-pertanyaan terbuka dan tertutup secara tepat, dan siswa mampu mengajukan pertanyaan secara efektif dan menjaga komunikasi timbal balik dengan temannya.

5. Sesi kelima: Keterampilan Konfrontasi

Dilaksanakan pada tanggal 12 Agustus 2019. Pada sesi kelima merupakan sesi keterampilan konfrontasi dimana seorang konselor sebaya dituntut mampu mengkomunikasikan pesan ganda (pesan yang 
bertentangan) tersebut kepada konseli dengan caracara yang dapat diterima oleh konseli. Tujuan keterampilan konfrontasi adalah diharapkan siswa mampu mengetahui kondisi-kondisi konfrontasi dan bagaimana cara menggunakan keterampilan konfrontasi secara efektif.

6. Sesi keenam: Keterampilan Merangkum

Dilaksanakan pada tanggal 13 Agustus 2019. Keterampilan ini sangat berguna bagi konselor sebaya dalam membantu konseli mengidentifikasi masalahnya. Tujuan dari keterampilan merangkum ini adalah siswa diharapkan mampu merangkum inti pembicaraan yang disampaikan oleh konseli, membantu konseli menemukan kesadaran baru tentang masalah yang sedang dialami, dan menumbuhkan kesadaran konseli untuk memandang masalah dari sudut pandang yang berbeda.

\section{Sesi ketujuh: Keterampilan Genuin}

Dilaksanakan pada tanggal 13 Agustus 2019. Berperilaku genuine merupakan perilaku jujur terhadap pikiran dan perasaan yang sedang dialami yang diekspresikan melalui perkataan dan tingkah laku apa adanya yang merupakan sikap dan tingkah laku konselor yang menyiratkan kesejatian atau keaslian (genuin).

8. Sesi kedelapan: Keterampilan pemecahan masalah Pada sesi kedelapaan merupakan sesi keterampilan pemecahan masalah. Pemecahan masalah merupakan aspek tindakandari suatu tingkah laku yang membawa suatu perubahan. Tujuan dari keterampilan pemecahan masalah ini adalah diharapkan siswa mampu memahami strategistrategi pemecahan masalah, memahami prosedurprosedur pemecahan masalah, dan siswa mampu mendemonstrasikan strategi-strategi pemecahan masalah
9. Posttest

Kegiatan posttest dilaksanakan pada tanggal 15 Agustus 2019. Pertemuan terakhir dengan membangun rapport dan membagikan posttest. Tujuan pelaksanaannya adalah untuk mengetahui tingkat keterampilan konselor sebaya dalam bidang kesehatan reproduksi remaja setelah pemberian pelatihan keterampilan konselor sebaya. Sekaligus peneliti mengucapkan terimakasih kepada peserta karena telah mengikuti semua kegiatan dengan baik.

\section{HASIL DAN PEMBAHASAN}

Hasil dari pelaksanaan pengabdian ini, akan dijabarkan dibawah ini sesuai dengan langkah-langkah atau metode pelaksanaan kegiatan pengabdian yang dilakukan. Setiap akhir sesi dilakukan evaluasi untuk mengetahui kemajuan peserta pada setiap sesi. Hasil dari masing-masing sesi dijabarkan sebagai berikut:

1. Sesi pertama: Pretest dan Pemberian informasi Seksualitas, HIV/AIDS, dan NAPZA

Hasil penilaian lembar kerja peserta pada kegiatan materi Seksualitas, HIV/AIDS, dan NAPZA adalah pada Tabel I.

Tabel I. Skor pretest kesehatan reproduksi remaja.

\begin{tabular}{cllc}
\hline No & \multicolumn{1}{c}{ Skor Rata-rata } & Kategori & Jumlah \\
\hline 1 & $X \geq 56$ & Tinggi & 3 \\
2 & $30 \leq X<56$ & Sedang & 12 \\
3 & $X<30$ & Rendah & 5 \\
\hline Total & & & 20 \\
\hline Mean $=40.8 ;$ SD $=14.9$ & & \\
\hline
\end{tabular}

\section{Sesi 2: Keterampilan Attending}

Hasil penilaian lembar kerja peserta pada keterampilan attending adalah pada Tabel II.

Tabel II. Skor Keterampilan Attending.

\begin{tabular}{cllc}
\hline No & \multicolumn{1}{c}{ Skor Rata-rata } & Kategori & Jumlah \\
\hline 1 & $X \geq 77$ & Tinggi & 3 \\
2 & $47 \leq X<77$ & Sedang & 13 \\
3 & $X<47$ & Rendah & 4 \\
\hline Total & & & 20 \\
\hline Mean $=61.9 ;$ SD 15 & & \\
\hline
\end{tabular}


3. Sesi 3 : Keterampilan Berempati

Hasil penilaian lembar kerja siswa pada keterampilan berempati adalah pada Tabel III.

Tabel III. Skor Keterampilan Berempati.

\begin{tabular}{cllc}
\hline No & \multicolumn{1}{c}{ Skor Rata-rata } & Kategori & Jumlah \\
\hline 1 & $\mathrm{X} \geq 78$ & Tinggi & 6 \\
2 & $53 \leq \mathrm{X}<78$ & Sedang & 11 \\
3 & $\mathrm{X}<53$ & Rendah & 3 \\
\hline Total & & & 20 \\
\hline \multicolumn{2}{l}{ Mean $=65.5 ; \mathrm{SD}=12.9$} & & \\
\hline
\end{tabular}

\section{Sesi 4 : Ketrampilan bertanya}

Hasil penilaian lembar kerja peserta pada keterampilan bertanya adalah pada Tabel IV.

Tabel IV. Skor Keterampilan Bertanya.

\begin{tabular}{cllc}
\hline No & \multicolumn{1}{c}{ Skor Rata-rata } & Kategori & Jumlah \\
\hline 1 & $\mathrm{X} \geq 74$ & Tinggi & 5 \\
2 & $44 \leq \mathrm{X}<74$ & Sedang & 11 \\
3 & $\mathrm{X}<44$ & Rendah & 4 \\
\hline Total & & & 20 \\
\hline Mean $=59.2 ; \mathrm{SD}=15.1$ & & \\
\hline
\end{tabular}

\section{Sesi 5: Keterampilan Konfrontasi}

Hasil penilaian lembar kerja peserta pada keterampilan konfrontasi adalah pada Tabel V.

Tabel V. Skor Keterampilan Konfrontasi.

\begin{tabular}{cllc}
\hline No & \multicolumn{1}{c}{ Skor Rata-rata } & Kategori & Jumlah \\
\hline 1 & $\mathrm{X} \geq 76$ & Tinggi & 5 \\
2 & $48 \leq \mathrm{X}<76$ & Sedang & 12 \\
3 & $\mathrm{X}<48$ & Rendah & 3 \\
\hline Total & & & 20 \\
\hline Mean $=62.2 ; \mathrm{SD}=14.2$ & & \\
\hline
\end{tabular}

\section{Sesi 6: Keterampilan Merangkum}

Hasil penilaian lembar kerja peserta pada keterampilan merangkum adalah pada Tabel VI.

Tabel VI. Skor Keterampilan Merangkum.

\begin{tabular}{cllc}
\hline No & \multicolumn{1}{c}{ Skor Rata-rata } & Kategori & Jumlah \\
\hline 1 & $\mathrm{X} \geq 80$ & Tinggi & 4 \\
2 & $52 \leq \mathrm{X}<80$ & Sedang & 12 \\
3 & $\mathrm{X}<52$ & Rendah & 4 \\
\hline Total & & \\
\hline \multicolumn{2}{l}{ Mean $=65.8 ; \mathrm{SD}=13.7$} & & 20 \\
\hline
\end{tabular}

\section{Sesi 7: Keterampilan Genuin}

Hasil penilaian lembar kerja peserta pada Keterampilan Genuin adalah pada Tabel VII.
Tabel VII. Skor Keterampilan Merangkum.

\begin{tabular}{cllc}
\hline No & \multicolumn{1}{c}{ Skor Rata-rata } & Kategori & Jumlah \\
\hline 1 & $X \geq 80$ & Tinggi & 5 \\
2 & $45 \leq X<80$ & Sedang & 10 \\
3 & $X<45$ & Rendah & 5 \\
\hline Total & & & 20 \\
\hline Mean $=62.7 ;$ SD $=17.3$ & & \\
\hline
\end{tabular}

8. Sesi 8 : Keterampilan Pemecahan masalah

Hasil penilaian lembar kerja peserta pada keterampilan pemecahan masalah adalah pada Tabel VIII.

Tabel VIII. Skor Keterampilan Pemecahan masalah.

\begin{tabular}{cllc}
\hline No & \multicolumn{1}{c}{ Skor Rata-rata } & Kategori & Jumlah \\
\hline 1 & $X \geq 83$ & Tinggi & 4 \\
2 & $54 \leq X<83$ & Sedang & 14 \\
3 & $X<54$ & Rendah & 2 \\
\hline Total & & & 20 \\
\hline Mean $=68.65 ;$ SD $=14.3$ & & \\
\hline
\end{tabular}

9. Posttest

Hasil penilaian posttest disajikan pada Tabel IX, sedangkan hasil analisis data tingkat keterampilan konselor sebaya dalam bidang kesehatan reproduksi remaja dengan jalan membandingkan hasil pretest dan posttest disajikan pada Tabel X.

Tabel IX. Skor posttest kesehatan reproduksi remaja.

\begin{tabular}{cllc}
\hline No & Skor Rata-rata & Kategori & Jumlah \\
\hline 1 & $\mathrm{X} \geq 76$ & Tinggi & 4 \\
2 & $59 \leq \mathrm{X}<76$ & Sedang & 13 \\
3 & $\mathrm{X}<59$ & Rendah & 3 \\
\hline Total & & & 20 \\
\hline Mean $=67.4 ; \mathrm{SD}=8.6$ & & \\
\hline
\end{tabular}

Tabel X. perbandingan jumlah peserta pada setiap kategori pretest dan posttest.

\begin{tabular}{lcc}
\hline \multicolumn{1}{c}{ Kategori } & Pretest & Posttest \\
\hline Tinggi & 3 & 4 \\
Sedang & 12 & 13 \\
Rendah & 5 & 3 \\
\hline Rerata & 40,8 & 67,4 \\
\hline
\end{tabular}

Berdasarkan hasil dari pelaksanaan pengabdian diatas, yang perlu menjadi bahan untuk didiskusikan adalah tentang Pelatihan konselor sebaya dipilih karena dalam perkembangannya, individu tidak dapat terlepas dari hubungannya dengan kelompok sosial lainnya, 
misalnya kelompok teman sebaya. Lingkungan/ kelompok ini akan ikut menentukan bagaimana individu itu berkembang. Tidak menutup kemungkinan adanya sifat kesebayaan ini, justru individu akan memperoleh keuntungan tertentu, Kelompok teman sebaya dapat dijadikan sebagai pengganti keluarga, dapat berfungsi menstabilkan pengaruh selama masa transisi sebagai sumber memperoleh harga diri, perlindungan dari paksaan orang dewasa.

Konseli-konseli yang memanfaatkan layanan konseling sebaya mampu melakukan identifikasi diri dengan teman sebaya mereka dan para konseli menganggap bahwa peer counselor (Konselor Sebaya) memiliki kemauan membangun jembatan komunikasi namun hal ini tidak berarti konselor sebaya mengganti keberadaan konselor professional, ia hanya membantu meningkatkan pelayanan. Tindal dan Gray (2015) berkeyakinan bahwa jika seseorang mempunyai suatu problem, maka pertama-tama ia akan bicara kepada teman atau kelompok sebayanya dan baru kemudian kepada konselor professional.

Hal senada diperkuat oleh Bramer (Erhamwilda, 2015) yang mengungkapkan bahwa banyak orang cenderung lebih suka mengemukakan persoalan (sharing atau curhat) kepada teman-teman dekatnya/teman sebayanya daripada kepada guru atau orang tua. Hal ini disebabkan karena sesama remaja tahu persis lika-liku masalah itu dan lebih spontan dalam mengadakan kontak. Privette \& Delawder (Erhamwilda, 2015) bahkan mengajukan asumsi bahwa kelompok atau temanteman sebaya lebih unggul dari pada tenaga-tenaga professional setidaknya dalam hal pembangunan hubungan (rapport) yang segera dan keefektifan yang ada dalam hubungan kesederajatan. Sementara itu faktor kesamaan pengalaman dan status non profesional yang dimiliki oleh konselor sebaya menyebabkan mereka dapat lebih diterima ketimbang penolong atau konselor profesional khususnya bagi konseli yang suka menghindar (Husni, 2017).

Dari beberapa pandangan diatas, konselor sebaya kiranya menjadi salah satu pilihan penting yang perlu dikaji dan diperhitungkan oleh kalangan konselor professional. Penting sebagai salah satu bantuan layanan konseling, khususnya untuk bantuan pengatasan masalah di kalangan remaja/pemuda yang seusia. Konseling sebaya dilakukan oleh orang non professional artinya bahwa individu yang berperan sebagai konselor sebaya bukanlah konselor professional atau ahli terapi. Dengan kata lain individu/tenaga non professional yang menjalankan peran pembantu itu adalah usianya kurang lebih sama dengan individu yang dilayani (Tindal \& Gray, 2015). Mereka adalah para siswa (remaja/pemuda/mahasiswa) yang memberikan bantuan kepada siswa lain dibawah bimbingan dan supervise konselor ahli/professional. Ini berarti peran dan kehadiran konselor ahli tetap diperlukan dalam konseling sebaya. Dengan demikian, nampak bahwa model hubungan dalam konseling sebaya bercorak triadic, yaitu hubungan yang terjadi antara konselor ahli/professional, konselor teman sebaya dan konseli teman sebaya.

Ada sejumlah dasar-dasar keterampilan komunikasi yang perlu dilatihkan pada konselor sebaya. Dasar-dasar keterampilan tersebut meliputi attending, empati, bertanya, konfrontasi, merangkum, genuine, dan pemecahan masalah. Strategi pelatihan konselor sebaya juga pernah dilakukan oleh Astiti di Provinsi Bali sejak tahun 2008 dengan jumlah peserta 20 orang SMA/SMK, tahun 2009 dilatih 20 orang SMA/SMK dan tahun 2010 peserta dari SMP berjumlah 10 orang dan SMA/SMK berjumlah 10 orang (berasal dari SMP dan SMA/SMK Kabupaten/Kota se-Bali) (Astiti, 2011). Dengan demikian, pemahaman mengenai kesehatan reproduksi remaja akan diberikan melalui pelatihan keterampilan 
konselor sebaya sehingga informasi yang remaja dapatkan menjadi benar dan tidak menjerumuskan serta diharapkan remaja bisa lebih bertanggungjawab terhadap diri sendiri dan lingkungan disekitarnya.

Melalui pengkajian yang bersifat pengembangan diharapkan dapat memperoleh pemahaman yang lebih komprehensif sehingga dapat dijadikan bahan masukan bagi pendidikan para konselor maupun calon konselor. Evaluasi dilakukan untuk mengetahui tingkat keberhasilan kegiatan yang telah dilakukan beserta hambatan-hambatan yang ditemukan. Dengan kata lain, kegiatan evaluasi merupakan usaha untuk mengetahui sejauh mana pelaksanaan program konseling teman sebaya dapat mencapai tujuan yang telah ditetapkan (Kurniawan, 2015).

Selain itu, melalui kegiatan evaluasi diharapkan akan dapat diperoleh umpan balik tentang efektivitas program konseling teman sebaya yang telah dilaksanakan. Berbekal umpan balik tersebut dapat diketahui sejauh mana derajat pencapaian tujuan beserta berbagai kendala yang ditemukan. Berdasarkan informasi-informasi tersebut dapat dirancang dan ditetapkan tindak lanjut kearah perbaikan, peningkatan, serta pengembangan program lebih lanjut tentang konseling teman sebaya (Basuki, 2013). Evaluasi dilakukan terhadap proses dan hasil dua kegiatan yaitu pelatihan konseling teman sebaya, dan pelaksanaan konseling teman sebaya.

\section{Evaluasi Pelatihan Konseling Teman Sebaya}

Evaluasi terhadap proses dan hasil pelatihan konseling teman sebaya dilakukan pada saat kegiatan pelatihan berlangsung, dan pada akhir setiap pertemuan yang membahas keterampilan atau teknik tertentu, dan atau di akhir pembahasan tentang tugas-tugas yang diberikan fasilitator. Evaluasi ditujukan terhadap aspek-aspek proses pelatihan yang meliputi kesungguhan/ antusiasme peserta mengikuti pelatihan, ketepatan dan ketersediaan alat bantu pelatihan, kesesuaian waktu pelatihan, serta ketepatan penggunaan metode pelatihan yang dipilih oleh konselor. Selain itu, derajat penguasaan peserta pelatihan terhadap pengetahuan, sikap, dan keterampilan yang dilatihkan, serta kebermanfaatan materi yang dirasakan peserta pelatihan menjadi indikator evaluasi hasil pelatihan konseling teman sebaya. Evaluasi dilakukan melalui refleksi baik perorangan maupun kelompok, dan pengamatan terhadap proses simulasi/bermain peran yang terjadi selama pelatihan berlangsung, serta melalui beberapa format yang dirancang dalam tiap-tiap modul pelatihan.

\section{Evaluasi Pelaksanaan Konseling Teman Sebaya}

Efektivitas pelaksanaan konseling teman sebaya dilihat dari frekuensi dan intensistas terjadinya proses "konseling" diantara teman sebaya, dan atau proses reveral dari "konselor" sebaya kepada konselor ahli. Selain itu, munculnya sahabat yang hangat, penuh perhatian, tulus membantu, tulus memberikan dukungan saat-saat menghadapi situasi yang sulit, serta dapat dipercaya juga merupakan indikator keberhasilan pelaksanaan konseling teman sebaya. Disamping indikator-indikator tersebut, meningkatnya skor post test yang diukur melalui soal-soal evaluasi juga menjadi indikator keberhasilan. Evaluasi dilakukan melalui refleksi baik perorangan maupun kelompok, dan pengamatan terhadap proses interaksi yang terjadi, baik dalam forum-forum yang sengaja didesain demi munculnya interaksi interpersonal antar peserta, maupun dalam berbagai kesempatan spontan selama peserta beraktivitas.

\section{KESIMPULAN}

Kegiatan pelatihan ketrampilan konseling sebaya menunjukan adanya peningkatan antara hasil pre test dan post test. Rerata pre test adalah 40,8 dan rerata post test meningkat menjadi 67,4. Pada pretes yang dilakukan 
kepada 20 responden berada pada kategori rendah dengan jumlah 5 orang, ketagori sedang 12 orang dan tinggi 3 orang. Hasil post test menunjukan peningkatan keterampilan konseling sebaya yaitu kategori rendah turun menjadi 3 orang, kategori sedang meningkat menjadi 13 orang dan kategori tinggi meningkat menjadi 4 orang.

\section{UCAPAN TERIMA KASIH}

Ucapan terima kasih serta penghargaan sebesarbesarnya tim pelaksana pengabdian yang berjudul "Pelatihan Keterampilan Konseling Sebaya Dalam Bidang Kesehatan Reproduksi Remaja" kepada Lembaga Penelitian dan Pengabdian kepada Masyarakat yang telah mendanai kegaitan ini melalui Hibah Pengabdian Kepada Masyarakat dengan skema PKMS, Kepala Sekolah, Guru dan Tenaga Kependidikan serta seluruh siswa-siswa SMK Kesehatan Muhammadiyah danSMAN1 Palangka Raya terutama 20 siswa yang menjadi peserta selama kegiatan pelaksanaan berlangsung, serta Seluruh tim pelaksana pengabdian yang telah banyak membantu untuk mensukseskan kegiatan pengabdian ini.

\section{REFERENSI}

Alyas. 2011. Implementasi Kebijakan Kesehatan Reproduksi Remaja Studi Kasus pada SMA Negeri 5 Makassar. Jurnal Ilmiah Ilmu Administrasi Publik: Jurnal Pemikiran dan Penelitian Administrasi Publik. 2(1):39-48. https://doi.org/10.26858/jiap.v2i1.873

Astiti, N.M. 2011. Hubungan Faktor Pelatihan Kesehatan Reproduksi dengan Implementasi Pasca Pelatihan pada Konselor Sebaya Kesehatan Reproduksi Remaja di Provinsi Bali. Tesis. Denpasar: Universitas Udayana.

Astuty, S.Y. 2013. Faktor-Faktor Penyebab Terjadinya Perkawinan Usia Muda Dikalangan Remaja Di Desa Tembung Kecamatan Percut Sei Tuan
Kabupaten Deli Serdang. Welfare State. 2(1):110.

Basuki, A. 2013. Efektivitas Pelayanan Konseling Kelompok Untuk Meningkatkan Keterampilan Komunikasi Interpersonal. Jurnal Penelitian Ilmu Pendidikan. 6(1):46-54. http://dx.doi.org/10.21831/jpipfip.v6i1.4740

Elvianasti, M., Roza, L. 2019. Pembentukan Kader Remaja Sehat Reproduksi di SMA Muhammadiyah 4 Jakarta. JPMB: Jurnal Pemberdayaan Masyarakat Berkarakter. 2(2):109117.

Erhamwilda. 2015. Konseling Sebaya Alternatif Layanan Bimbingan Konseling di Sekolah. Yogyakarta: Media Akademia.

Filho, E.A.R., Lima, J.C., Neto, J.S.P., Montarroyos, U. 2011. Essential fatty acids for premenstrual syndrome and their effect on prolactin and total cholesterol levels: a randomized, double blind, placebo-controlled study. Reproductive Health. 8:2. https://doi.org/10.1186/1742$4755-8-2$

Fitriyani, I.N. 2016. Pengembangan Metode Pelatihan Dengan Problem Card Dalam Peningkatan Pengetahuan Dan Sikap Remaja Tentang Kesehatan Reproduksi. JHE (Journal of Health Education). 1(1):21-25.

Husni, M. 2017. Konseling Sebaya Dalam Islam Untuk Meningkatkan Keterampilan Konseling Sebaya Dengan Mind Skills. Pedagogik: Jurnal Pendidikan.4(1):47-61.

Kurniawan, L. 2015. Pengembangan Program Layanan Bimbingan Dan Konseling Komprehensif Di SMA. Jurnal Psikologi Pendidikan dan Konseling: Jurnal Kajian Psikologi Pendidikan dan Bimbingan Konseling. 1(1):1-8. https://doi.org/10.26858/jpkk.v1i1.1351

Muslikah, Haryadi, S., Amin, Z. 2016. Pengembangan Model Peer Counseling sebagai Media Pengalaman Praktik Konseling. Indonesian Journal of Guidance and Counseling: Theory and Application. 5(3):48-52.

Purbono, I.A., Prabawati, M., Tarma. 2015. Tingkat Pengetahuan Remaja Tentang Kesehatan Reproduksi. FamilyEdu: Jurnal Pendidikan Kesejahteraan Keluarga. 1(2):135-149. 
Rizqi, M.A., Nashori, F., Astuti, Y.D. 2017. Pelatihan Konseling Kesehatan Remaja Untuk Meningkatkan Efikasi Diri Konselor Sebaya Pada Siswa Sekolah Menengah Atas. JIP (Jurnal Intervensi Psikologi). 9(1):64-78. https://doi.org/10.20885/intervensipsikologi .vol9.iss1.art5

Tindal, J.A., Gray, H.D. 2015. Peer Counseling. Indian: Accelerated Development Inc. 